\title{
Plant Richness-Biomass Relationships in Restored Northern Great Plains Grasslands (USA)
}

\author{
Mario E. Biondini, ${ }^{1}$ Jack E. Norland, ${ }^{2}$ and Carolyn E. Grygiel ${ }^{2}$ \\ ${ }^{1}$ Range Science Graduate Program, School of Natural Resource Sciences, North Dakota State University, \\ NDSU Dep. 7510, P.O. Box 6050, Fargo, ND 58108-6050, USA \\ ${ }^{2}$ Natural Resources Management Interdisciplinary Program, School of Natural Resource Sciences, \\ North Dakota State University, Fargo, ND 58108-6050, USA
}

Correspondence should be addressed to Mario E. Biondini, mario.biondini@ndsu.edu

Received 30 November 2010; Revised 4 March 2011; Accepted 25 March 2011

Academic Editor: Shibu Jose

Copyright (c) 2011 Mario E. Biondini et al. This is an open access article distributed under the Creative Commons Attribution License, which permits unrestricted use, distribution, and reproduction in any medium, provided the original work is properly cited.

\begin{abstract}
We investigated plant richness-biomass relationships in tall grass (Field 1, 12 years) and mixed grass (Field 2, 5 years) restoration experiments located in the northern Great Plains grasslands (USA). They were organized as randomized factorial experiments with fertilization rates ( $\mathrm{N}$ or $\mathrm{P}$ ) and number of species as factors. Results were as follows: (1) above ground biomass (AGB) increased and year-to-year variability declined with plant species and functional form richness. (2) AGB was higher when the species had various combinations: (a) high relative growth rates, root density, root surface area, $\mathrm{N}$ or $\mathrm{P}$ uptake rates, and $\mathrm{N}$ use efficiency; (b) low root-to-shoot ratio and root plasticity. (3) Biomass stability was positively related to high root surface area in Field 1 and $\mathrm{N}$ use efficiency and P uptake rates in Field 2. (4) Invasion of nonseeded species declined with plant species and functional form richness.
\end{abstract}

\section{Introduction}

There is a need to better understand the links between biological diversity, ecosystem function, and sustainability of natural and managed ecosystems. Results from a variety of experiments like the USA LTER Cedar Creek [1] and the European BIODEPH [2, 3], meta-analysis of published works $[4,5]$, and comparisons of productivity-diversity relationship across Eurasian, Europe, and North America grasslands [6] have improved our understanding of this problem. An extensive review of the available literature by Hooper et al. [7] reached the following conclusions. (1) Certain combinations of species are complementary and can increase average rates of productivity. (2) Susceptibility to invasion, while strongly influenced by species composition, generally decreases with increasing species richness. (3) The combination of species that respond differently to environmental perturbations can reduce ecosystem variability.

Diversity, production, and stability linkages are of particular interest regarding prairie restoration in the USA as a consequence of the Conservation Reserve Program whose objectives include, among others, the restoration, long-term productivity, and permanence of prairie ecosystems [8]. More than 10 million ha have been enrolled in the program, with the vast majority being restored to prairies [9]. Fifty three percent of these prairies, however, are dominated by only 2 species, while another $18 \%$ have at most 5 species [10], so diversity is an issue.

In 1998 our group began a long-term experiment to investigate the relationship among plant diversity, production, stability, and susceptibility to invasion in restored northern tall grass prairies [11]. Tilman et al. [12] have shown that long-term research in multiple sites is needed to determine the generality of initial results, understand the effects of nonrandom community assembly and disassembly, and determine the implications of biodiversity for ecosystem management. On that premise, we continued to monitor the first experiment (now 12 years old) and in 2005 added a new site in the northern mixed grass prairie which represents the dry portion of the northern Great Plains precipitation gradient [13]. The specific objectives of both experiment are to (1) determine the relationship among plant diversity, 
production, stability, and susceptibility to invasion and (2) determine what combinations of growth rates, nutrient use efficiency, root architecture, and root physiology of plants within a seed mixture have the highest impact in peak above ground biomass and its year-to-year variability. This paper reports results after 12 and 6 years, respectively, of restoration.

\section{Methods}

2.1. Location and Site Characteristics. The experiments were located in two distinct ecological areas. The first experiment (Field 1) was located at the NDSU Albert Ekre Grassland Preserve, in south eastern North Dakota, USA $\left(46^{\circ} 33^{\prime} \mathrm{N}, 97^{\circ} 7^{\prime} \mathrm{W}\right.$, elevation $295 \mathrm{~m}$, average annual precipitation $538 \mathrm{~mm}$ ). This site is in the northern tall grass prairie and represents the wet end of the northern Great Plains precipitation gradient [13]. The soils belong to the Embden-Tiffany fine sandy loam series (coarse-loamy, mixed, superactive, frigid Pachic Hapludolls and frigid Typic Endoaquolls): 0-3\% slopes, moderately well drained, and a combined A\&B depth of $69 \mathrm{~cm}$. The area had been planted in the past with corn and soybeans. It was disked several times in 1997 and 1998 to reduce the seed bank and was treated with Roundup (Monsanto, St. Louis, Mo, USA) prior to planting to minimize plant regrowth. The average soil $\mathrm{N}$ prior to planting was $4.6 \mu \mathrm{g} \cdot \mathrm{g}^{-1}( \pm 0.23)$ while the corresponding $\mathrm{P}$ was $41 \mu \mathrm{g} \cdot \mathrm{g}^{-1}( \pm 2)$. The large soil $\mathrm{P}$ was a carryover from prior soybean fertilization.

The second experiment (Field 2) was located at the NDSU Dickinson Research Extension Center $\left(46^{\circ} 53^{\prime} 52.27^{\prime \prime} \mathrm{N}, 102^{\circ} 49^{\prime} 42.63^{\prime \prime} \mathrm{W}\right.$, elevation $730 \mathrm{~m}$, average annual precipitation $405 \mathrm{~mm}$ ). The site is in the northern mixed grass prairie and represents the dry portion of the northern Great Plains precipitation gradient. The soils belong to the Morton and Farland series (fine-silty, mixed, superactive, frigid Argiustolls): 0-5\% slopes, well drained, and a combined A\&B depth of $86 \mathrm{~cm}$. The land had been idle or occasionally used as a hay lot since the 1930s when it was planted with Bromus inermis and Agropyron cristatum. The area was treated three times with Roundup in 2005 as well as lightly harrowed before and after seeding (no disking to prevent erosion). Soil $\mathrm{N}$ prior to planting was $9.3 \mu \mathrm{g} \cdot \mathrm{g}^{-1}$ $( \pm 1.7)$ while the corresponding $\mathrm{P}$ was $4.6 \mu \mathrm{g} \cdot \mathrm{g}^{-1}( \pm 1.1)$.

2.2. Selection of Species Mixtures. We followed the protocols implemented at the Cedar Creek LTER site [1]. At each level of species richness, replications were constructed by randomly selecting from the species pool (Table 1) the appropriate number of species and functional forms. This approach maximizes the probability that the mean response for a given richness level will be independent of any particular species combination. The functional form classification of the species was derived by Levang-Brilz and Biondini [14] and Biondini [11].

2.3. Experimental Design. The Field 1 experiment was started in 1998. It was organized as a completely randomized factorial design with 3 factors and 10 replications per factor combination. Factor 1 (nutrient type) consisted of applications of either $\mathrm{N}$ or P. Factor 2 (nutrient level) consisted of 2 fertilization rates. The high rate was $200 \mathrm{Kg} \cdot \mathrm{ha}^{-1} \cdot \mathrm{yr}^{-1}$ for $\mathrm{N}$ or $40 \mathrm{Kg} \cdot \mathrm{ha}^{-1} \cdot \mathrm{yr}^{-1}$ for $\mathrm{P}$, while the low rate was $20 \mathrm{Kg} \cdot \mathrm{ha}^{-1} \cdot \mathrm{yr}^{-1}$ for $\mathrm{N}$ or $4 \mathrm{Kg} \cdot \mathrm{ha}^{-1} \cdot \mathrm{yr}^{-1}$ for P. Factor 3 (species richness) consisted of treatments with $1,2,5,10$, or 20 plant species. Each replication consisted of the given number of species drawn randomly from the list in Table 1. The replications are $9 \mathrm{~m}^{2}(3 \times 3 \mathrm{~m})$ in size with a $1 \mathrm{~m}$ buffer zone. We used a low fertilization treatment rather than a control for two reasons: (1) the initial soil $\mathrm{N}$ was low in comparison to the adjacent native prairies in the region (4.6 versus $10-20 \mu \mathrm{g} \cdot \mathrm{g}^{-1}$ ) because of the repeated two-year pretreatment disking and (2) the imbalance between soil $\mathrm{N}$ and $\mathrm{P}$.

The majority of the plots were planted in the fall, except for a few that were planted in the following spring [11]. The seeding rates were 400 live seed $\cdot \mathrm{m}^{-2}$ with equal amounts for each species. Seeds were broadcasted and covered with a thin layer of soil to improve seedling establishment, since forbs with small seeds do not do well with drillseeding [17]. For the first 5 years (2000-2004), all plots were manually weeded throughout the growing season to eliminate unwanted species. The plots were burned in 2007 to replicate the standard prescribed burning management for the region [18].

The Field 2 experiment was started in the fall of 2005 with some plantings done in the spring of 2006. It was organized as a completely randomized factorial design with 2 factors and 10 replications per factor combination. Factor 1 consisted of no fertilization, $\mathrm{N}\left(200 \mathrm{Kg} \cdot \mathrm{ha}^{-1} \cdot \mathrm{yr}^{-1}\right)$, and $\mathrm{P}$ $\left(40 \mathrm{Kg} \cdot \mathrm{ha}^{-1} \cdot \mathrm{yr}^{-1}\right)$. Factor 2 consisted of 5 levels of species richness: 1 species ( $\mathrm{Sp}$ ) belonging to 1 functional form (FF), 2 Sp belonging to $2 \mathrm{FF}, 5$ Sp belonging to $2 \mathrm{FF}, 5 \mathrm{Sp}$ belonging to $3 \mathrm{FF}, 10 \mathrm{Sp}$ belonging to $3 \mathrm{FF}, 10 \mathrm{Sp}$ belonging to $4 \mathrm{FF}$, and $20 \mathrm{Sp}$ belonging to $5 \mathrm{FF}$. The replications are $5 \mathrm{~m} \times$ $5 \mathrm{~m}$ in size with a $3 \mathrm{~m}$ buffer zone between plots. Species were selected and planted at the density described for Field 1. Since 2006 was an extremely dry year $(290 \mathrm{~mm}$ of growing season precipitation) the plots were irrigated $(\approx 100 \mathrm{~mm})$ to allow for a reasonable establishment (otherwise the experiment would have been lost). Irrigation was not used afterward.

In both sites, $\mathrm{N}$ and $\mathrm{P}$ were applied in the early spring of each year (after the snow had melted) using Sierra slow release fertilizer prills (Pursell Technologies, Inc.) The nutrients are released in a fairly even pattern over a 6-7-month period according to tests provided by the manufacture.

2.4. Sampling Methods. The plots in Field 1 were not sampled or weeded during the first growing season; instead, the top $15 \mathrm{~cm}$ of the weedy species were periodically cut with a line trimmer to prevent reseeding. Weeding was started in 2000 when all nonseeded species were uprooted on a yearly basis and lasted until 2004. The plots were sampled from 2000 to 2004 and then (after the 2007 prescribed burning) in 20092010 . 
TABLE 1: Species used in the experiment. FF represents the functional form types derived by Levang-Brilz and Biondini [14] based on the morphological and physiological characteristics listed in this table. $\beta$ and $\rho$ are scaling constants that relate root biomass (RB (g)) to root lateral spread $\left(\mathrm{RLS}(\mathrm{m})=\alpha * \mathrm{RB}^{\beta}\right)$ and root surface area $\left(\mathrm{RSA}\left(\mathrm{m}^{2}\right)=\eta * \mathrm{RB}^{\rho}\right)$, while $\tau$ is a scaling constant for root plasticity $(\tau=0$ no plasticity) derived by Biondini [15] using data from Johnson and Biondini [16]. R:S is the root-to-shoot ratio; RGR is relative growth rate $\left(\mathrm{g} \cdot \mathrm{g}^{-1} \cdot \mathrm{d}^{-1}\right)$; NUE and PUE are $\mathrm{N}$ and $\mathrm{P}$ use efficiency $\left(\mathrm{g} \cdot \mathrm{gN}^{-1}\right.$ and $\mathrm{g} \cdot \mathrm{gP} \mathrm{P}^{-1}$, resp.); Imax- $\mathrm{N}$ and Imax-P are the maximum $\mathrm{N}$ or $\mathrm{P}$ uptake rate per unit of root surface area $\left(\mathrm{g} \cdot \mathrm{m}^{-2} \cdot \mathrm{d}^{-1}\right)$. Nomenclature follows the PLANTS Database (http://plants.usda.gov/), National Plant Data Center, Baton Rouge, La, USA.

\begin{tabular}{|c|c|c|c|c|c|c|c|c|c|c|c|}
\hline Species & $\mathrm{C} 3 / \mathrm{C} 4$ & FF & $\beta$ & $\rho$ & $\mathrm{R}: \mathrm{S}$ & RGR & NUE & PUE & Imax-N & Imax-P & $\tau$ \\
\hline \multicolumn{12}{|l|}{ Grasses } \\
\hline Agropyron cristatum & $\mathrm{C} 3$ & G1 & 0.007 & 0.589 & 0.81 & 0.11 & 44.41 & 181.03 & 0.3576 & 0.1082 & 0.28 \\
\hline Andropogon gerardii & $\mathrm{C} 4$ & G1 & 0.515 & 0.746 & 1.57 & 0.10 & 71.46 & 251.04 & 0.1961 & 0.0669 & 0.08 \\
\hline Bouteloua curtipendula & $\mathrm{C} 4$ & G2 & 0.631 & 0.326 & 0.55 & 0.13 & 60.02 & 244.34 & 0.1628 & 0.0522 & 0.02 \\
\hline Bouteloua gracilis & $\mathrm{C} 4$ & G2 & 0.584 & 0.368 & 0.76 & 0.09 & 50.75 & 153.60 & 0.3927 & 0.0671 & 0.00 \\
\hline Bromus inermis & C3 & G1 & 0.496 & 1.066 & 0.71 & 0.11 & 71.96 & 173.48 & 0.3695 & 0.0855 & 0.08 \\
\hline Calamovilfa longifolia & $\mathrm{C} 4$ & G3 & 0.372 & 0.289 & 0.68 & 0.11 & 54.66 & 262.83 & 0.3289 & 0.0756 & 0.25 \\
\hline Elymus canadensis & $\mathrm{C} 3$ & G3 & 0.439 & 0.473 & 1.09 & 0.13 & 55.18 & 190.45 & 1.3480 & 0.3221 & 0.34 \\
\hline Hesperostipa comata & C3 & G2 & 0.668 & 0.479 & 0.74 & 0.06 & 43.22 & 190.16 & 0.2413 & 0.0646 & 0.26 \\
\hline Hordeum jubatum & $\mathrm{C} 3$ & G1 & 0.667 & 0.719 & 0.87 & 0.15 & 54.58 & 129.28 & 0.2433 & 0.0641 & 0.27 \\
\hline Koeleria macrantha & $\mathrm{C} 3$ & $\mathrm{G} 2$ & 0.476 & 0.556 & 0.49 & 0.10 & 55.69 & 152.26 & 0.0635 & 0.0202 & 0.29 \\
\hline Nassella viridula & $\mathrm{C} 3$ & G2 & 0.602 & 0.358 & 0.66 & 0.10 & 53.55 & 225.76 & 1.0824 & 0.2198 & 0.00 \\
\hline Panicum virgatum & $\mathrm{C} 4$ & G1 & 0.202 & 0.884 & 0.61 & 0.10 & 50.79 & 131.91 & 0.1359 & 0.0485 & 0.24 \\
\hline Pseudoroegneria spicata & C3 & G3 & 0.527 & 0.593 & 1.01 & 0.11 & 45.85 & 168.50 & 0.7674 & 0.2222 & 0.13 \\
\hline Poa pratensis & $\mathrm{C} 3$ & G2 & 0.544 & 0.296 & 0.70 & 0.13 & 52.43 & 149.07 & 0.1501 & 0.0521 & 0.39 \\
\hline Schizachyrium scoparium & $\mathrm{C} 4$ & G1 & 0.534 & 0.697 & 0.98 & 0.11 & 62.69 & 250.78 & 0.2043 & 0.0611 & 0.31 \\
\hline Sorghastrum nutans & $\mathrm{C} 4$ & G1 & 0.348 & 0.514 & 0.98 & 0.09 & 71.76 & 201.86 & 0.4986 & 0.1439 & 0.00 \\
\hline Sporobolus cryptandrus & $\mathrm{C} 4$ & G3 & 0.443 & 0.434 & 1.05 & 0.14 & 48.14 & 185.95 & 1.3337 & 0.3761 & 0.36 \\
\hline \multicolumn{12}{|l|}{ Forbs } \\
\hline Achillea millefolium & $\mathrm{C} 3$ & $\mathrm{~F} 1$ & 0.411 & 0.968 & 1.67 & 0.14 & 39.42 & 98.14 & 0.4363 & 0.1517 & 0.92 \\
\hline Allium stellatum & C3 & $\mathrm{F} 2$ & 0.532 & 0.569 & 1.85 & 0.06 & 52.20 & 141.27 & 0.1190 & 0.0281 & 0.10 \\
\hline Artemisia dracunculus & $\mathrm{C} 3$ & $\mathrm{~F} 1$ & 0.588 & 0.703 & 0.39 & 0.13 & 43.20 & 146.88 & 0.8507 & 0.2529 & 0.15 \\
\hline Artemisia frigida & $\mathrm{C} 3$ & F3 & 0.376 & 0.794 & 0.44 & 0.09 & 50.88 & 142.78 & 0.8166 & 0.0739 & 0.45 \\
\hline Asclepias verticillata & $\mathrm{C} 3$ & F1 & 0.338 & 0.595 & 1.07 & 0.09 & 66.14 & 123.01 & 0.4105 & 0.1241 & 0.39 \\
\hline Aster ericoides & $\mathrm{C} 3$ & F3 & 0.488 & 0.623 & 0.96 & 0.12 & 33.08 & 142.82 & 1.3150 & 0.4292 & 0.50 \\
\hline Astragalus Canadensis & $\mathrm{C} 3$ & F3 & 0.726 & 0.401 & 1.97 & 0.13 & 44.36 & 144.55 & 2.9724 & 0.7098 & 0.57 \\
\hline Chrysopsis villosa & $\mathrm{C} 3$ & $\mathrm{~F} 1$ & 0.478 & 0.461 & 0.75 & 0.09 & 38.60 & 127.01 & 0.1858 & 0.0345 & 0.76 \\
\hline Cirsium arvense & $\mathrm{C} 3$ & $\mathrm{~F} 1$ & 0.584 & 0.718 & 0.98 & 0.11 & 63.31 & 114.99 & 0.2466 & 0.1083 & 0.03 \\
\hline Coreopsis lanceolata & $\mathrm{C} 3$ & $\mathrm{~F} 1$ & 0.317 & 0.618 & 0.67 & 0.11 & 52.34 & 163.83 & 0.3450 & 0.0737 & 0.35 \\
\hline Dalea purpurea & $\mathrm{C} 3$ & F3 & 0.932 & 0.853 & 0.90 & 0.09 & 38.93 & 121.61 & 1.9311 & 0.5538 & 0.73 \\
\hline Gaillardia aristata & $\mathrm{C} 3$ & $\mathrm{~F} 1$ & 0.170 & 0.969 & 0.95 & 0.08 & 32.44 & 96.28 & 0.2267 & 0.0750 & 0.85 \\
\hline Galium boreale & $\mathrm{C} 3$ & $\mathrm{~F} 2$ & 0.368 & 0.567 & 1.42 & 0.08 & 87.28 & 249.76 & 0.0817 & 0.0185 & 0.25 \\
\hline Geum triflorum & $\mathrm{C} 3$ & $\mathrm{~F} 1$ & 0.410 & 0.703 & 0.67 & 0.08 & 53.80 & 127.38 & 0.3213 & 0.0850 & 0.33 \\
\hline Grindelia squarrosa & $\mathrm{C} 3$ & F3 & 0.449 & 0.580 & 0.89 & 0.14 & 39.26 & 95.99 & 0.7372 & 0.2184 & 0.82 \\
\hline Helianthus maximiliani & $\mathrm{C} 3$ & F3 & 0.590 & 0.325 & 0.92 & 0.13 & 44.66 & 97.03 & 0.7170 & 0.3607 & 0.81 \\
\hline Helianthus rigidus & $\mathrm{C} 3$ & $\mathrm{~F} 1$ & 0.211 & 0.596 & 0.81 & 0.09 & 31.31 & 65.97 & 0.3629 & 0.0912 & 0.30 \\
\hline Linum perenne & $\mathrm{C} 3$ & F3 & 0.113 & 0.618 & 2.52 & 0.09 & 46.58 & 158.57 & 0.1931 & 0.0456 & 0.27 \\
\hline Lupinus perennis & $\mathrm{C} 3$ & $\mathrm{~F} 1$ & 1.260 & 1.000 & 1.19 & 0.10 & 50.36 & 98.67 & 0.6303 & 0.2251 & 1.15 \\
\hline Melilotus officinalis & $\mathrm{C} 3$ & $\mathrm{~F} 1$ & 0.559 & 1.076 & 2.78 & 0.14 & 42.94 & 82.54 & 1.2851 & 0.1579 & 0.38 \\
\hline Oenothera biennis & $\mathrm{C} 3$ & F3 & 0.355 & 0.258 & 1.11 & 0.19 & 81.00 & 87.14 & 1.3504 & 0.6483 & 0.56 \\
\hline Potentilla arguta & $\mathrm{C} 3$ & $\mathrm{~F} 1$ & 0.358 & 1.001 & 0.46 & 0.10 & 47.20 & 153.39 & 0.3926 & 0.1058 & 0.25 \\
\hline Ratibida columnifera & C3 & $\mathrm{F} 1$ & 0.411 & 0.802 & 0.41 & 0.10 & 41.75 & 87.56 & 0.9931 & 0.3586 & 0.50 \\
\hline Rosa arkansana & $\mathrm{C} 3$ & F3 & 0.455 & 0.456 & 0.64 & 0.18 & 59.83 & 346.72 & 2.0071 & 0.3075 & 1.08 \\
\hline Rudbeckia hirta & $\mathrm{C} 3$ & $\mathrm{~F} 1$ & 0.647 & 0.703 & 0.64 & 0.12 & 49.59 & 113.30 & 1.0892 & 0.2979 & 0.80 \\
\hline Solidago missouriensis & $\mathrm{C} 3$ & $\mathrm{~F} 1$ & 0.526 & 0.121 & 0.69 & 0.10 & 38.33 & 264.75 & 0.0297 & 0.0025 & 0.72 \\
\hline Solidago rigida & $\mathrm{C} 3$ & $\mathrm{~F} 1$ & 0.245 & 0.790 & 1.21 & 0.10 & 59.12 & 137.05 & 0.3477 & 0.0882 & 0.42 \\
\hline
\end{tabular}


TABle 1: Continued.

\begin{tabular}{lccccccccccc}
\hline Species & C3/C4 & FF & $\beta$ & $\rho$ & R:S & RGR & NUE & PUE & Imax-N & Imax-P & $\tau$ \\
\hline Taraxacum officinale & C3 & F1 & 0.348 & 1.073 & 0.72 & 0.12 & 53.88 & 136.76 & 0.5504 & 0.0875 & 0.61 \\
Tragopogon dubius & C3 & F1 & 0.578 & 0.920 & 0.77 & 0.10 & 41.33 & 110.82 & 0.6571 & 0.2260 & 0.00 \\
Verbena stricta & C3 & F1 & 0.283 & 0.766 & 0.59 & 0.11 & 36.70 & 110.46 & 0.5721 & 0.1693 & 1.59 \\
Vicia americana & C3 & F1 & 0.356 & 0.545 & 1.01 & 0.08 & 38.17 & 102.65 & 0.4790 & 0.1797 & 0.79 \\
\hline
\end{tabular}

Peak above-ground biomass by species was estimated by clipping four, $0.25 \mathrm{~m}^{2}$ quadrats per replication at the end of July or August (depending on the growing conditions for that year). The clipped biomass was separated by species and the materials oven-dried at $60^{\circ} \mathrm{C}$ for $12 \mathrm{hr}$ and weighed. The quadrats were randomly located within each replication avoiding areas that had been clipped in the past 2 years. Seeded species and functional form richness were determined annually by visually surveying the entire $9 \mathrm{~m}^{2}$ of each replication. These are the numbers used for species and functional form richness in the pertinent statistical analyses.

Invasive species (defined as nonseeded species) were estimated with two methods. In 2003-2004 invasive species were estimated using foliar cover. For that purpose, two $0.5 \mathrm{~m}^{2}$ quadrats were randomly located within each plot (in areas not clipped in the previous 2 years) just prior to weeding (June). The foliar cover of invasive species was visually estimated using the Daubenmire cover scale [19]. After weeding was stopped in 2004, invasive species in 20092010 were estimated on a biomass basis within the quadrats used to estimate seeded biomass.

The plots of Field 2 were not sampled during the first growing season but were subjected to the same top cutting treatment of Field 1 . The plots of Field 2 were not subjected to weeding since they had not been disked, and the dryness of the area created a risk of damaging seeded species. Peak above-ground biomass by species was estimated as in Field 1, except that we used two $0.5 \mathrm{~m}^{2}$ quadrats. Seeded and invasive species were clipped by species within these plots. Seeded species and functional form richness were determined annually by visually surveying the entire $25 \mathrm{~m}^{2}$ of each replication.

2.5. Statistical Analysis. In experimental designs of this type, species and functional form richness are not orthogonal, independent factors; however, the nonorthogonality problem can be solved by using principal components analysis (PCA) on the correlation matrix of species and functional form richness [20]. In this analysis, PC1 captures the combined effects of species and functional richness, while PC2 provides information on the independent effect of functional form richness (if any). The data we used in the PCA were from the yearly species richness surveys. A PC was selected for further analyses if its variance $(\lambda)$ was larger than a random $\lambda$ calculated via the broken stick method [21]. The scores for the selected PCs were calculated using PC-ORD Version 5 (MJM Software Design) and used as a proxy for species and functional form richness in the various regression analyses described below.
We followed Tilman [22] and used the coefficient of variation $(\mathrm{CV})$ in peak above-ground biomass over the study length as a measurement of biomass stability: the higher the $\mathrm{CV}$, the lower the stability. As another measure of stability, we also calculated the upper bound (maximum) and lower bound (minimum) of above-ground peak biomass over the length of the experiments.

Differences among treatments in peak above-ground biomass were analyzed using a repeated observation factorial analysis of variance (ROAOV), with years being the repeated observation factor [23]. After the 2007 burn, some of the replications in Field 1 were affected by various degrees of pocket gopher (Geomys bursarius) disturbances. Consequently the ROAOV analysis for Field 1 was done using 6 undisturbed replications per treatment combination rather than the original ten (ROAOV requires a balanced design). In cases where no replications within a treatment combination had been affected by pocket gophers, the 6 replications were selected at random. For the regression analyses we used all of the nondisturbed replications.

The functional relationship of species and functional form richness (as defined by the PC's) with above-ground peak biomass, $\mathrm{CV}$, and minimum and maximum peak aboveground biomass was tested via regression analyses. Statistical differences in the regression slopes for the various nutrient $x$ rate combinations were tested using methods outlined by Snedecor and Cochran [24]. We ran the regressions involving species and functional form richness versus above-ground biomass using the entire data set for each experiment, rather than year by year, treatment averages within a year, or overall experiment averages. As expected, this approach reduced the overall $r^{2}$ but it was better suited to ascertain if the connection between species and functional form richness and above-ground biomass was strong enough to overcome the replication effects and year-to-year variability.

We used stepwise regression to parse what combinations of growth rates, nutrient use efficiency, root architecture, and root physiology had the most impact in plant community above-ground biomass and its year-to-year variability. The approach was as follows. (1) All the growth and root parameters (Table 1) were standardized to the $0-1$ range to make slopes comparable. (2) For each plot we calculated a weighted average (weighted by plant species biomass) of the standardized plant growth and root parameter. (3) These weighted averages were used as independent variables in a stepwise regression where above-ground biomass or its CV constituted the dependent variables [25]. The randomization of seed mixtures plus the various levels of species and functional form richness made for a very robust analysis. 


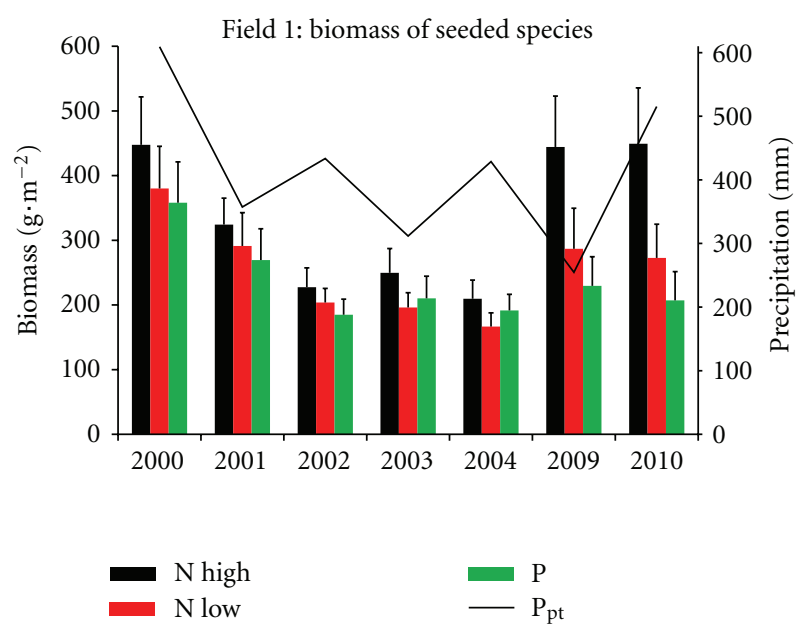

FIGURE 1: Field 1: growing season precipitation ( $\mathrm{mm}$ ) and average above-ground peak biomass $\left(\mathrm{g} \cdot \mathrm{m}^{2}\right)$ of seeded species for the high $\mathrm{N}$, low $\mathrm{N}$, and the combined $\mathrm{P}$ treatments. Vertical bars represent a $95 \%$ confidence interval.

\section{Results}

The principal component analysis for both the Field 1 and 2 experiments resulted in only 1 significant axis, PC1. Field 1 had a $\lambda=1787>$ broken stick $\lambda=1407$ which accounted for $88 \%$ of total variance, while Field 2 had a $\lambda=479>$ broken stick $\lambda=379$ accounting for $95 \%$ of total variance. In Field 1 and 2 PC1 was positively correlated with both species and functional form richness: $r^{2}=0.9, P<.001$. In all the regression analyses that follow, PC1 was used to characterize species and functional form richness.

\subsection{Biomass as Related to Nutrient Applications}

Field 1. The average biomass of seeded species differed among the nutrient combinations (Nutr*Fert, $P<$ .02 , see Table 6$)$ across all species richness treatments: $336( \pm 20) \mathrm{g} \cdot \mathrm{m}^{-2}$ in the high $\mathrm{N}$ treatment versus 246 $( \pm 15) \mathrm{g} \cdot \mathrm{m}^{-2}$ in the low $\mathrm{N}$ plus $\mathrm{P}$ treatments. Average biomass declined across nutrient combinations (Nutr $*$ Year, $P<.05$, See Table 6) from 2000 to 2004, mostly as a result of changes in growing season precipitation, and then increased (substantially in the high $\mathrm{N}$ treatment) after the 2007 prescribed burning (Figure 1). There was a significant nutrient type $\times$ plant richness $\times$ year interaction (Nutr $*$ Treat $*$ Year, $P<.01$, See Table 6 ), the details of which are described in the next section.

Field 2. Nutrient treatments did not have a significant effect in seeded species biomass either as a main effect or in interactions with year or species richness (see Table 7). It did however significantly affect the nonseeded species biomass (see Table 8). Overall, nonseeded biomass was higher (Nutr, $P<.001$, see Table 8$)$ in the $\mathrm{N}$ treatment $\left(345 \pm 15 \mathrm{~g} \cdot \mathrm{m}^{-2}\right)$ than that in the control and $P$ treatments $\left(234 \pm 28 \mathrm{~g} \cdot \mathrm{m}^{-2}\right)$, and it substantially increased (Nutr*Year, $P<.001$, see Table 8) from the 2007-2008 to the 2009-2010 growing

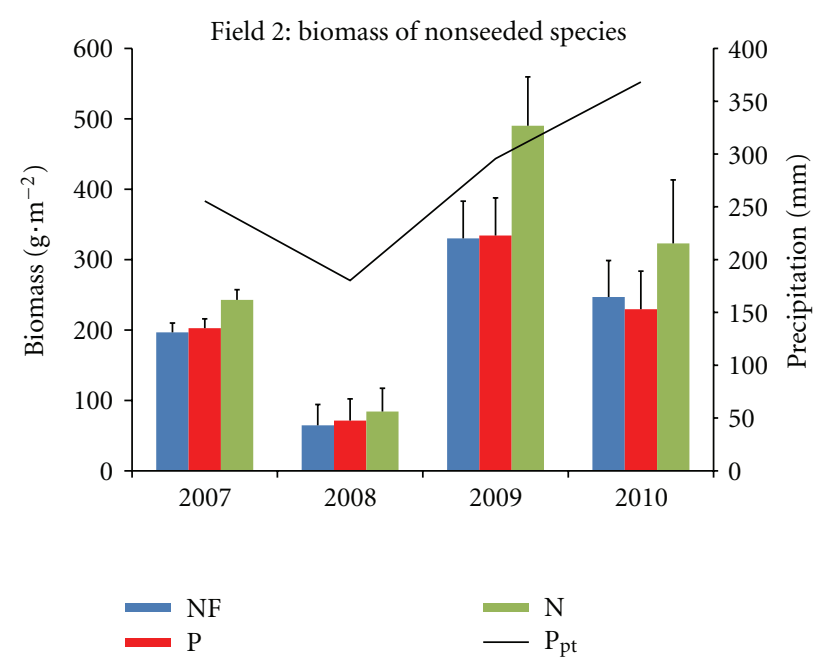

FIGURE 2: Field 2: growing season precipitation $(\mathrm{mm})$ and average above-ground peak biomass $\left(\mathrm{g} \cdot \mathrm{m}^{2}\right)$ of nonseeded species for the $\mathrm{N}$, $\mathrm{P}$, and nonfertilized (NF) treatments. Vertical bars represent a $95 \%$ confidence interval.

seasons $\left(152 \pm 21 \mathrm{~g} \cdot \mathrm{m}^{-2}\right.$ versus $389 \pm 55 \mathrm{~g} \cdot \mathrm{m}^{-2}$, Figure 2$)$. The change was driven mostly by a $50 \%$ increase in growing season precipitation ( 218 versus $332 \mathrm{~mm}$, Figure 2) to which nonseeded species responded more rapidly than the seeded species. As in Field 1, there was a significant plant richness $\times$ year interaction for both seeded and nonseeded biomass (Treat $*$ Year, $P<.01$, See Tables 7 and 8 ).

\subsection{Biomass as Related to Species and Functional Form Richness}

Field 1. Total seeded biomass was positively correlated with species and functional form richness $(P<.05)$, with the regression lines differing among the high $\mathrm{N}$, low $\mathrm{N}$, and all $\mathrm{P}$ treatments (Figure 3 ). While the low $r^{2}$ was expected due to large year-to-year variability, the upward trends were nevertheless significant. The response was driven by increases in both minimum and maximum biomass (over 11 years) as a function of species and functional form richness. Minimum biomass was unaffected by nutrient levels $\left(r^{2}=\right.$ $0.41, P<.01)$, while maximum biomass was $r^{2}=0.2,0.13$, and $0.49(P<.01)$ for the high $\mathrm{N}$, low $\mathrm{N}$, and $\mathrm{P}$ treatments. The biomass CV (year to year) of seeded species declined substantially with species and functional form richness but was unaffected by the nutrient type and rate combinations (Figure 4).

The stepwise regression showed a few similarities and a variety of differences among the high $\mathrm{N}$, low $\mathrm{N}$, and all the $\mathrm{P}$ treatments (Table 2). In all treatments above-ground biomass was positively correlated with $\mathrm{N}$ use efficiency (NUE). In the $\mathrm{N}$ treatments it was also positively correlated with root surface area (the $\rho$ slope) (Table 2). There were some commonalities between the low $\mathrm{N}$ and $\mathrm{P}$ treatments. In both cases above-ground biomass was positively correlated with relative growth rate (RGR) and negatively correlated 
TABLE 2: Field 1: stepwise regression relating peak biomass to the weighted (by biomass) plant parameters associated with the various species composition treatments. The parameter definitions are shown in Table 1. Note: the coefficient values represent the relative importance of each variables since they were all standardized to the 0 -1 range before use.

\begin{tabular}{|c|c|c|c|c|c|c|c|}
\hline \multicolumn{4}{|c|}{ High $\mathrm{N}$ treatment $\left(r^{2}=0.14, P<.0001\right)$} & \multicolumn{4}{|c|}{ Low $\mathrm{N}$ treatment $\left(r^{2}=0.21, P<.0001\right)$} \\
\hline Variables & Coefficient & SE & $P$ & Variables & Coefficient & SE & $P$ \\
\hline $\operatorname{Imax}-\mathrm{N}$ & 438.4 & 78.7 & .0001 & NUE & 439.9 & 92.0 & .0001 \\
\hline NUE & 237.7 & 45.6 & .0001 & RGR & 254.0 & 101.4 & .0126 \\
\hline \multirow[t]{3}{*}{$\rho$} & 200.9 & 85.5 & .0192 & $\rho$ & 133.4 & 42.3 & .0017 \\
\hline & & & & PUE & -348.4 & 81.0 & .0001 \\
\hline & & & & $\mathrm{R}: \mathrm{S}$ & -177.7 & 74.9 & .0181 \\
\hline \multicolumn{8}{|c|}{ P treatment $\left(r^{2}=0.23, P<.0001\right)$} \\
\hline Variables & & \multicolumn{2}{|c|}{ Coefficient } & \multicolumn{2}{|c|}{ SE } & & $P$ \\
\hline RGR & & \multicolumn{2}{|c|}{713.5} & \multicolumn{2}{|c|}{74.7} & & .0001 \\
\hline Imax-P & & \multicolumn{2}{|c|}{562.4} & \multicolumn{2}{|c|}{91.1} & & .0001 \\
\hline NUE & & \multicolumn{2}{|c|}{533.9} & \multicolumn{2}{|c|}{68.5} & & .0001 \\
\hline$\delta$ & & \multicolumn{2}{|c|}{414.5} & \multicolumn{2}{|c|}{61.7} & & .0001 \\
\hline Imax-N & & \multicolumn{2}{|c|}{-508.7} & \multicolumn{2}{|c|}{105.0} & & .0001 \\
\hline PUE & & \multicolumn{2}{|c|}{-373.4} & \multicolumn{2}{|c|}{61.8} & & .0001 \\
\hline$\beta$ & & \multicolumn{2}{|c|}{-196.7} & \multicolumn{2}{|c|}{41.9} & & .0001 \\
\hline$\tau$ & & \multicolumn{2}{|c|}{-190.1} & \multicolumn{2}{|c|}{56.5} & & .0008 \\
\hline$\rho$ & & \multicolumn{2}{|c|}{-157.8} & \multicolumn{2}{|c|}{41.9} & & .0002 \\
\hline $\mathrm{R}: \mathrm{S}$ & & \multicolumn{2}{|c|}{-127.2} & \multicolumn{2}{|c|}{41.7} & & .0023 \\
\hline
\end{tabular}

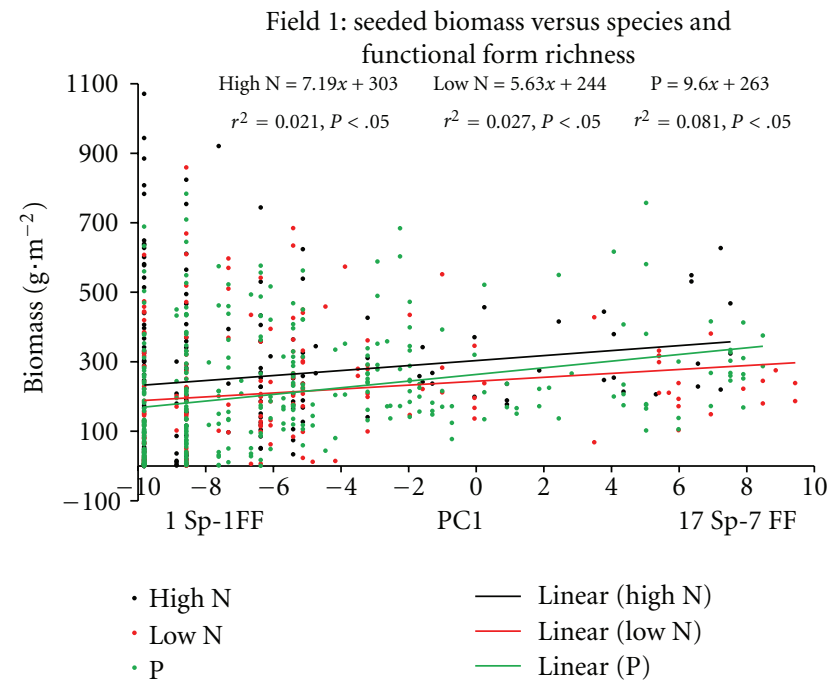

FIGURE 3: Field 1: relationship between seeded species aboveground peak biomass $\left(\mathrm{g} \cdot \mathrm{m}^{2}\right.$ ) and PC1 (a proxy for species and functional form richness). Sp: species; FF: functional form (numbers in the $x$-axis represent the range in Sp and FF).

with root-to-shoot ratios (R:S) and phosphorous use efficiency (PUE) (Table 2). A similar stepwise regression for the biomass CV resulted in a different set of variables (Table 3 ): a positive correlation with $\mathrm{R}: \mathrm{S}$ and root plasticity (the $\tau$ constant) and a negative one with $\rho$.

Field 2. Total seeded biomass was positively correlated with species and functional form richness $(P<.01)$, with the

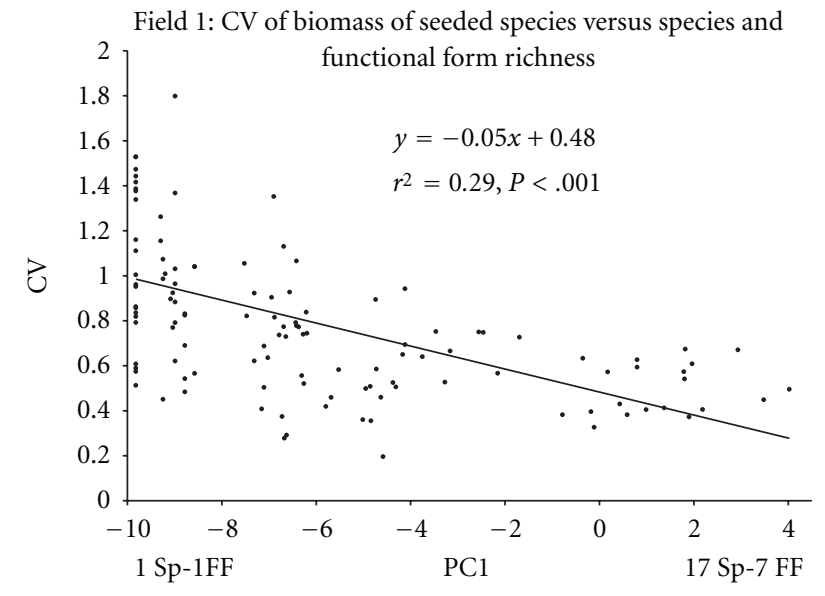

Figure 4: Field 1: relationship between the coefficient of variation (CV) of the above-ground peak biomass of seeded species over the 11-year experiment and PC1 (a proxy for species and functional form richness). Sp: species; FF: functional form (numbers in the $x$-axis represent the range in $\mathrm{Sp}$ and $\mathrm{FF}$ ).

regression lines differing among the nutrient treatments (Figure 5). The results, however, were driven primarily by one treatment in factor 2 (treatment 7 ) that had an average of 6 species and 4 functional forms (Figure 6): $316 \pm 60 \mathrm{~g} \cdot \mathrm{m}^{-2}$ versus $101 \pm 48$ for the other treatments (Treat* Year, $P<.001$, see Table 7). Minimum biomass and maximum biomass (over 4 years) increased as a function of species and functional form richness $\left(r^{2}=0.33\right.$, 


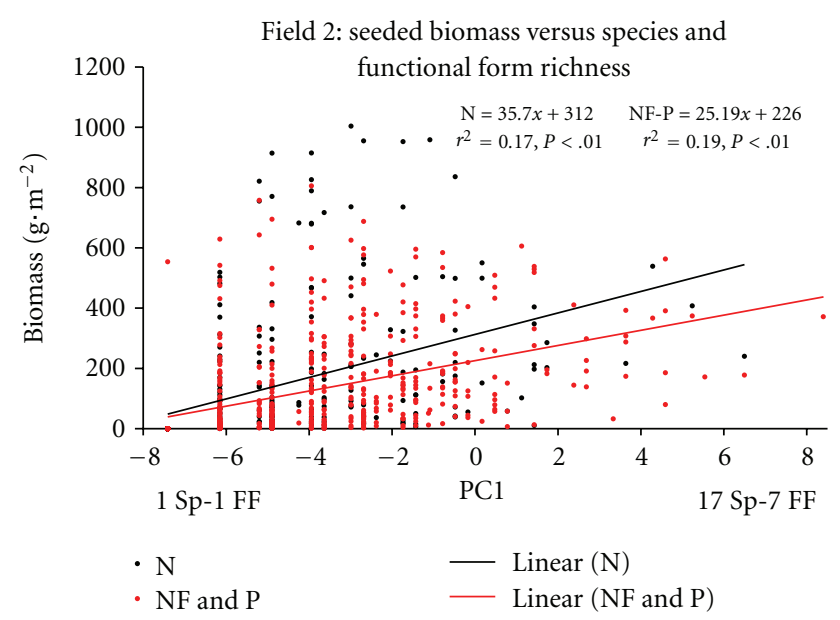

Figure 5: Field 2: relationship between seeded species aboveground peak biomass $\left(\mathrm{g} \cdot \mathrm{m}^{2}\right)$ and PC1 (a proxy for species and functional form richness). Sp: species; FF: functional form (numbers in the $x$-axis represent the range in Sp and FF).

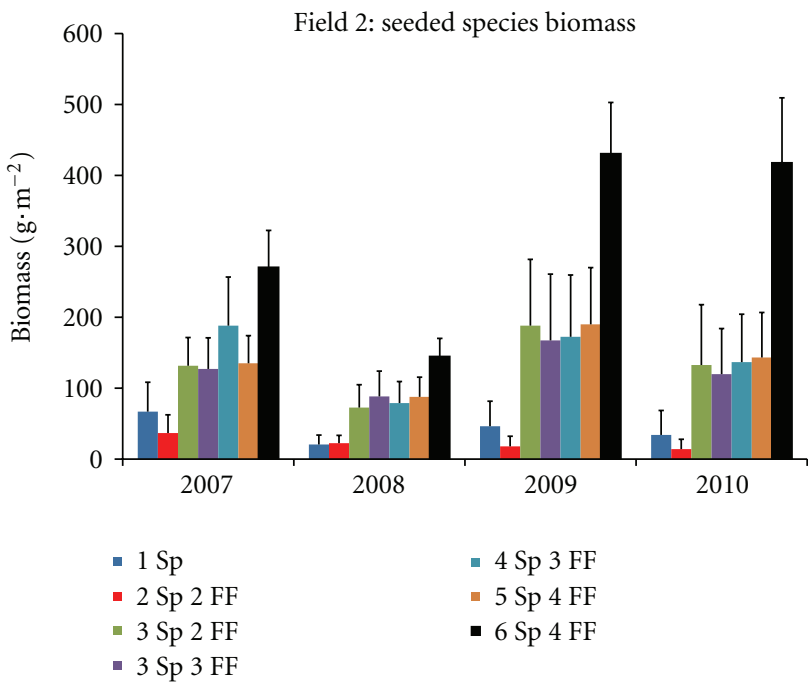

FIGURE 6: Field 2: relationship between seeded species aboveground peak biomass $\left(\mathrm{g} \cdot \mathrm{m}^{2}\right)$ and the average species and functional form richness of seeded species. Sp: species; FF: functional form. Vertical bars represent a 95\% confidence interval.

$P<.01$ ) but were unaffected by nutrient levels (Nutr, $P>.5$, Nutr*Year, $P>.15$, Year $*$ Nutr $*$ Treat, $P>.9$, see Table 7$)$. The CV of seeded biomass was inversely related to species and functional form richness (Figure 7).

The stepwise regression showed a variety of similarities and a few differences among the $\mathrm{N}$, the control, and $\mathrm{P}$ treatments (Table 4). In all of the nutrient treatments seeded biomass was positively correlated with RGR and $\mathrm{N}$ uptake rate per root surface area (Imax-N) and negatively correlated with $\tau$ and root lateral spread (large $\beta$ equal low root density). The control and $\mathrm{P}$ treatments were also positively correlated with $\rho$ and negatively correlated with NUE and $\mathrm{R}$ : S (Table 4). The stepwise regression for the CV of seeded biomass resulted in a positive correlation with Imax-N and

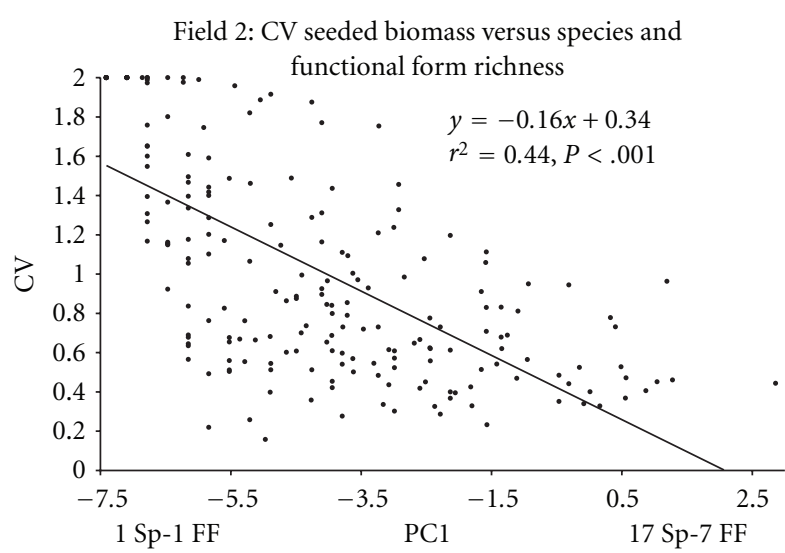

FIGURE 7: Field 2: relationship between the coefficient of variation (CV) of the above-ground peak biomass of seeded species over the 4-year experiment and PC1 (a proxy for species and functional form richness). Sp: species; FF: functional form (numbers in the $x$-axis represent the range in $\mathrm{Sp}$ and $\mathrm{FF}$ ).

TABLE 3: Field 1: stepwise regression relating peak biomass CV (between years) to the weighted (by biomass) plant parameters associated with the various species composition treatments. See Table 2 for further details.

\begin{tabular}{lccc}
\hline & All treatments $\left(r^{2}=0.18, P<.0001\right)$ & \\
Variables & Coefficient & SE & $P$ \\
\hline $\mathrm{R}: \mathrm{S}$ & 0.7 & 0.2 & .0001 \\
$\tau$ & 0.3 & 0.1 & .0171 \\
$\rho$ & -0.2 & 0.1 & .0057 \\
\hline
\end{tabular}

$\beta$ (low root density), and negatively correlated with Imax-P and NUE (Table 5).

\subsection{Invasive Species as Related to Seeded Species and Func- tional Form Richness}

Field 1. The cover of nonseeded species in 2003-2004 was inversely correlated with seeded species and functional form richness $\left(r^{2}=0.32, P<.01\right)$ and unaffected by nutrient levels. The biomass of nonseeded species after the 2007 burning (2009-2010) was inversely related to the biomass of seeded species with the relationship affected by nutrient treatments (Figure 8). It was also inversely related to species and functional form richness (Trt, $P<.0001$, see Table 9), affected by nutrient type (Nutr $* \operatorname{Trt}, P<.05$, see Table 9 ), but unaffected by nutrients $\times$ rates combinations $(P>.9$, Nutr*Fert*Trt, see Table 9).

Field 2. The nonseeded species biomass was inversely related to the species and functional form richness of seeded species (Figure 9), while its CV was positively correlated $\left(r^{2}=\right.$ $0.12, P<.01)$, suggesting that nonseeded species are unstable in diverse plant communities. Overall, the biomass of nonseeded species was inversely related to the biomass of seeded ones with the relationship affected by nutrient treatments (Figure 10). 
TABLE 4: Field 2: stepwise regression relating peak biomass to the weighted (by biomass) plant parameters associated with the various species composition treatments. See Table 2 for further details.

\begin{tabular}{|c|c|c|c|c|c|c|c|}
\hline \multicolumn{4}{|c|}{$\mathrm{N}$ treatment $\left(r^{2}=0.45, P<.0001\right)$} & \multicolumn{4}{|c|}{$\mathrm{P}$ and Non fertilized treatment $\left(r^{2}=0.45, P<.0001\right)$} \\
\hline Variables & Coefficient & SE & $P$ & Variables & Coefficient & SE & $P$ \\
\hline RGR & 752.61 & 173.43 & .0001 & RGR & 671.86 & 75.20 & .0001 \\
\hline Imax-N & 297.71 & 127.44 & .0205 & $\rho$ & 194.54 & 37.10 & .0001 \\
\hline$\beta$ & -1028.09 & 82.49 & .0001 & Imax-N & 167.03 & 61.76 & .0071 \\
\hline \multirow[t]{4}{*}{$\tau$} & -417.75 & 110.59 & .0002 & NUE & -696.99 & 124.10 & .0001 \\
\hline & & & & $\tau$ & -555.37 & 70.25 & .0001 \\
\hline & & & & $\beta$ & -523.47 & 43.72 & .0001 \\
\hline & & & & $\mathrm{R}: \mathrm{S}$ & -187.21 & 39.71 & .0001 \\
\hline
\end{tabular}

Field 1: seeded versus nonseeded biomass (2009-2010)

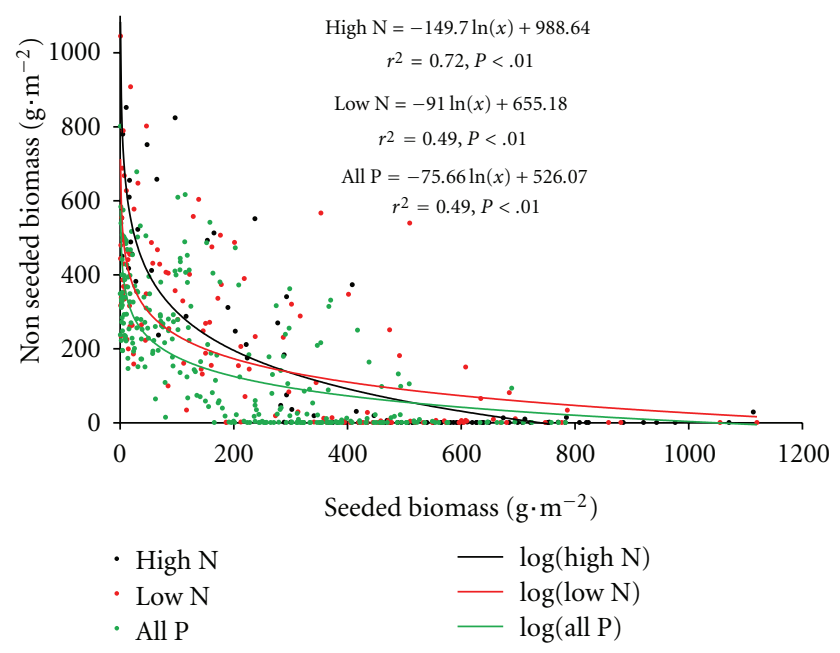

Figure 8: Field 1: relationship between the biomass $\left(\mathrm{g} \cdot \mathrm{m}^{-2}\right)$ of seeded and nonseeded species for 2009-2010 as affected by nutrient levels.

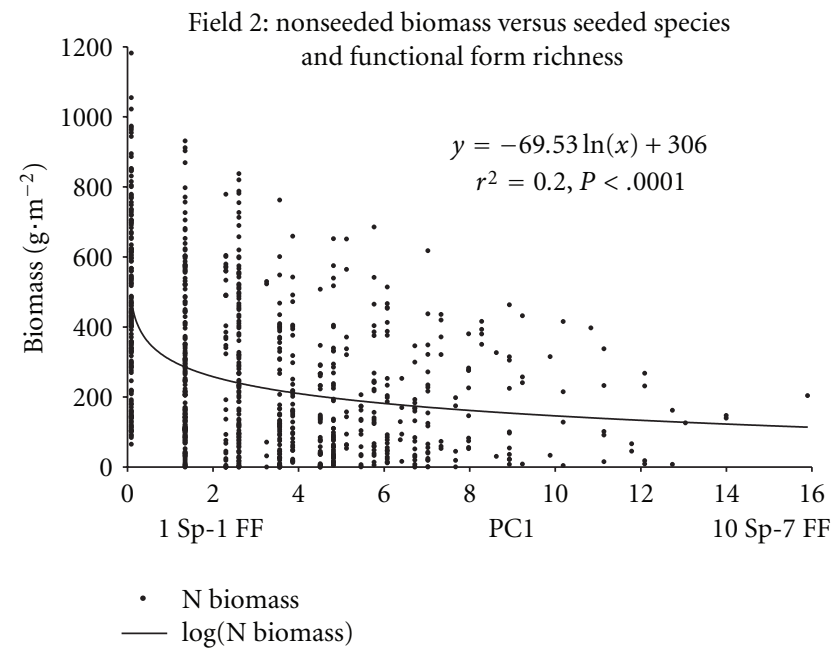

FIGURE 9: Field 2: relationship between the biomass $\left(\mathrm{g} \cdot \mathrm{m}^{-2}\right)$ of nonseeded (invasive) species and PC1 (a proxy for species and functional form richness). Sp: species; FF: functional form (numbers in the $x$-axis represent the range in Sp and FF).
TABLE 5: Field 2: stepwise regression relating peak biomass CV (between years) to the weighted (by biomass) plant parameters associated with the various species composition treatments. See Table 2 for further details.

\begin{tabular}{|c|c|c|c|}
\hline \multicolumn{4}{|c|}{ All treatments $\left(r^{2}=0.31, P<.0001\right)$} \\
\hline Variables & Coefficient & SE & $P$ \\
\hline Imax-N & 2.69 & 0.52 & .0001 \\
\hline$\beta$ & 0.66 & 0.18 & .0003 \\
\hline Imax-P & -2.13 & 0.54 & .0001 \\
\hline NUE & -1.91 & 0.39 & .0001 \\
\hline
\end{tabular}

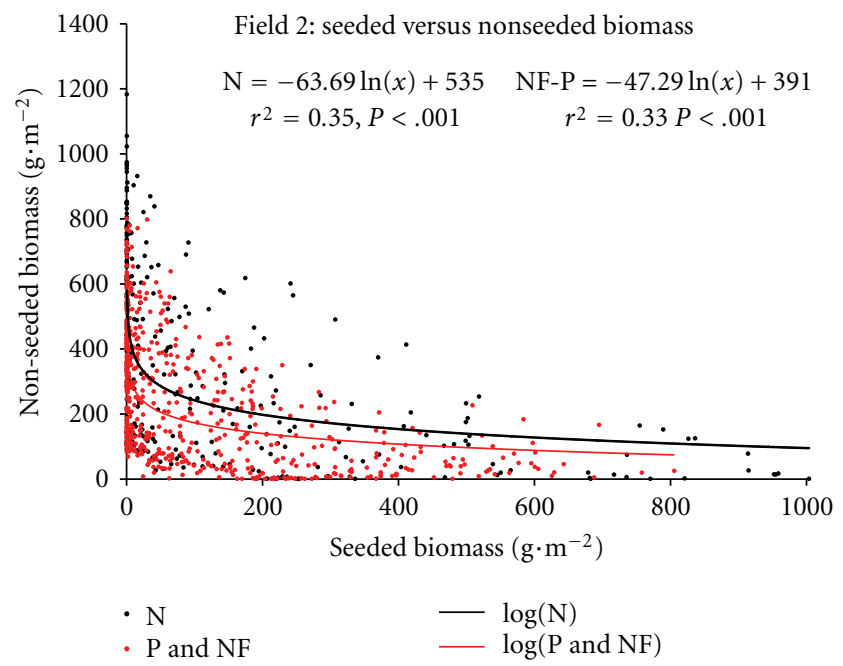

Figure 10: Field 2: relationship between the biomass $\left(\mathrm{g} \cdot \mathrm{m}^{-2}\right)$ of seeded and nonseeded species for 2005-2010.

\section{Discussion}

The hypothesis that plant diversity increases production is based on the proposition that there are enough differences among plants in physiology, morphology, resource requirements, and life histories so that mixtures of several species can better utilize limiting resources than single species [26]. Biondini [11] described how plant morphological and physiological characteristics affected biomass production for 
the first 6 years of growth in Field 1. A similar analysis after 12 years showed many similarities but two major differences in the high $\mathrm{N}$ treatment. The first one was the substantial difference in biomass between the high $\mathrm{N}$ treatment and the other ones in 2009-2010 (446 \pm 82 versus $\left.241 \pm 51 \mathrm{~g} \cdot \mathrm{m}^{-2}\right)$. The second one involved the plant parameters that correlated with above-ground biomass. After 12 years of growth, N root uptake rates and root surface area continue to be positively related to above ground biomass, but relative growth rates were not, and more interestingly $\mathrm{N}$ use efficiency went from a negative to a positive correlation with above-ground biomass. For the low $\mathrm{N}$ and all $\mathrm{P}$ treatments results from both 6 and 12 years of growth were similar. Interestingly, the stepwise regression analysis for Field 2 (5 years of growth) showed similar results to the one from the first 6 years of Field 1. In both instances, biomass was higher when the species in the mixture had (1) high relative growth rates, root density, root surface area, or $\mathrm{N}$ root uptake rates; (2) low root-to-shoot ratio (high biomass allocation to stems and leaves). There were three results in Field 2 that were unexpected. We had hypothesized that in the more drier Field 2, N use efficiency, root plasticity, and biomass allocation to roots would be positively correlated with biomass production. The results, however, were the opposite: they were either unrelated or negatively correlated. It appears, thus, that in the early stages of establishment, relative growth rates, root surface area, $\mathrm{N}$ root uptake rates, and root density play a more important role than the allocation of biomass to nonphotosynthetic tissue (roots) or the efficiency of nutrient utilization. A review of the literature has shown similar results regarding root biomass. Bessler et al. [27] in a study of grasslands in Germany reported that root-to-shoot ratios in mixtures were lower than expected from the monoculture performance of the species present in the mixtures. They speculated that interactions among species led to reduced biomass partitioning to belowground organs. In our study the inverse relationship between rootto-shoot ratios and biomass has been consistent in both Fields 1 and 2 and across time spans.

Results from both Fields 1 and 2 show a consistent positive relationship between above-ground biomass and species and functional form richness with the regression lines related to fertilization levels. Minimum biomass and maximum biomass were also positively related to species and functional form richness. These results are mostly in agreement with current evidence [7], including the fertilization response $[28,29]$. For example, Cardinale et al. [5] summarized the results of 44 experiments that have manipulated the richness and showed that, in $79 \%$ of them, treatments with multiple species produced an average of 1.7 times more biomass than monocultures. The standard interpretation has been that higher biomass is simply an artifact of the increased probability of selecting highly productive species when using a diverse mixture. Cardinale et al. [5], however, concluded that although productive species do indeed contribute to the species richness-biomass link, these contributions are equalled or exceeded by species complementarity and that the magnitude of complementarity increases the longer the experiments are run, thus the need for long-term
TABLe 6: Analysis of variance for total seeded biomass $\left(\mathrm{g} \cdot \mathrm{m}^{-2}\right)$ in Field 1. For details regarding the statistical analysis see Section 2.

\begin{tabular}{lcccc}
\hline Source & DF & MS & F & $P$ \\
\hline Factor 1 (Nutr) & 1 & 120003 & 4.22 & $\mathbf{. 0 4 3}$ \\
Factor 2 (Fert) & 1 & 36746 & 1.29 & .258 \\
Factor 3 (Treat) & 4 & 1060813 & 37.3 & $\mathbf{. 0 0 1}$ \\
Nutr $*$ Fert & 1 & 162245 & 5.7 & $\mathbf{. 0 1 9}$ \\
Nutr $*$ Treat & 4 & 24438 & 0.86 & .491 \\
Fert $*$ Treat & 4 & 9049 & 0.32 & .865 \\
Nutr $*$ Fert $*$ Treat & 4 & 53600 & 1.88 & .119 \\
Error 1 & 100 & 28444 & & \\
Year & 6 & 186097 & 7.71 & $\mathbf{. 0 0 1}$ \\
Nutr $*$ Year & 6 & 58604 & 2.43 & $\mathbf{. 0 3 4}$ \\
Fert $*$ Year & 6 & 17305 & 0.72 & .611 \\
Treat $*$ Year & 24 & 57765 & 2.39 & $\mathbf{. 0 0 1}$ \\
Nutr $*$ Fert $*$ Year & 6 & 34975 & 1.45 & .205 \\
Nutr $*$ Treat $*$ Year & 24 & 48878 & 2.03 & $\mathbf{. 0 0 6}$ \\
Fert $*$ Treat $*$ Year & 24 & 21350 & 0.88 & .607 \\
Nutr $*$ Fert $*$ Treat $*$ Year & 24 & 17879 & 0.74 & .784 \\
Error 2 & 600 & 24135 & & \\
\hline
\end{tabular}

TABLe 7: Analysis of variance for total seeded biomass $\left(\mathrm{g} \cdot \mathrm{m}^{-2}\right)$ in Field 2. For details regarding the statistical analysis see Section 2.

\begin{tabular}{lcccc}
\hline Source & DF & MS & F & $P$ \\
\hline Factor 1 (Nutr) & 2 & 39911 & 0.66 & .520 \\
Factor 2 (Treat) & 6 & 1082148 & 17.78 & $\mathbf{. 0 0 1}$ \\
Nutr*Treat & 12 & 16661 & 0.27 & .993 \\
Error 1 & 189 & 60872 & & \\
Year & 3 & 367083 & 27.05 & $\mathbf{. 0 0 1}$ \\
Nutr $*$ Year & 6 & 21296 & 1.57 & .154 \\
Treat $*$ Yr & 18 & 69701 & 5.14 & .001 \\
Nutr $*$ Treat $*$ Year & 36 & 6939 & 0.51 & .993 \\
Error 2 & 567 & 13573 & & \\
\hline
\end{tabular}

TABLE 8: Analysis of variance for total nonseeded biomass $\left(\mathrm{g} \cdot \mathrm{m}^{-2}\right)$ in Field 2. For details regarding the statistical analysis see Section 2.

\begin{tabular}{lcccc}
\hline Source & DF & MS & F & $P$ \\
\hline Factor 1 (Nutr) & 2 & 1151649 & 19.9 & $\mathbf{. 0 0 1}$ \\
Factor 2 (Treat) & 6 & 716164 & 12.37 & $\mathbf{. 0 0 1}$ \\
Nutr*Treat & 12 & 15200 & 0.26 & .990 \\
Error 1 & 189 & 57885 & & \\
Year & 3 & 4739603 & 282.01 & $\mathbf{. 0 0 1}$ \\
Nutr $*$ Year & 6 & 206499 & 12.29 & $\mathbf{. 0 0 1}$ \\
Treat $*$ Year & 18 & 131764 & 7.84 & $\mathbf{. 0 0 1}$ \\
Nutr*Treat $*$ Year & 36 & 9847 & 0.59 & .981 \\
Error 2 & 567 & 16807 & & \\
\hline
\end{tabular}

studies. Gillman and Wright [4] did a more extensive metaanalysis involving 159 productivity-plant species richness relationships from 131 published studies. They found that relationships were positive regardless of the grain of the study and that unimodal relationships were not dominant even in 
TABLE 9: Analysis of variance for total nonseeded biomass $\left(\mathrm{g} \cdot \mathrm{m}^{-2}\right)$ in Field 1 for 2009-2010. For details regarding the statistical analysis see Section 2.

\begin{tabular}{lcccc}
\hline Source & DF & MS & F & $P$ \\
\hline Factor 1 (Nutr) & 1 & 1474468 & 17.24 & $\mathbf{. 0 0 0}$ \\
Factor 2 (Fert) & 1 & 30884 & 0.36 & .549 \\
Factor 3 (Treat) & 4 & 1973507 & 23.07 & $\mathbf{. 0 0 1}$ \\
Nutr $*$ Fert & 1 & 81136 & 0.95 & .333 \\
Nutr $*$ Treat & 4 & 371723 & 4.35 & $\mathbf{. 0 0 3}$ \\
Fert $*$ Treat & 4 & 2620 & 0.03 & .998 \\
Nutr $*$ Fert $*$ Treat & 4 & 3326 & 0.04 & .997 \\
Error 1 & 100 & 85541 & & \\
Year & 1 & 19225 & 1.51 & .222 \\
Nutr $*$ Year & 1 & 552 & 0.04 & .836 \\
Fert $*$ Year & 1 & 104834 & 8.24 & $\mathbf{. 0 0 5}$ \\
Treat $*$ Year & 4 & 63246 & 4.97 & $\mathbf{. 0 0 1}$ \\
Nutr $*$ Fert $*$ Year & 1 & 232 & 0.02 & .893 \\
Nutr $*$ Treat $*$ Year & 4 & 25529 & 2.01 & .099 \\
Fert $*$ Treat $*$ Year & 4 & 15395 & 1.21 & .312 \\
Nutr $*$ Fert $*$ Treat $*$ Year & 4 & 17982 & 1.41 & .235 \\
Error 2 & 100 & 12726 & & \\
\hline
\end{tabular}

studies of fine grain or small spatial extent. A similar linear relationship was found by Bai et al. [6] on productivitydiversity relationship in the Eurasian Steppe. In the northern Great Plains, however, results from Guo et al. [30] suggest that, when seeded diversity spans a sufficiently broad range (2-32 species), the diversity-productivity relationship may be nonmonotonic, with productivity first increasing and then declining when richness reaches 16 species. Our studies were conducted in the same region but are more extensive and of a longer duration; nevertheless, our linear response is consistent with Guo et al. [30] since our effective species richness was at or below the 16 species threshold.

Another characteristic of biomass-richness relationships is the role of dominance. Results from recent modeling and empirical studies indicate that it is the combination of plant richness and biomass evenness that leads to increased productivity [31-35]. That was not the case in our study, where, in the treatments with the highest biomass and species richness, the dominant species accounted for at least $60 \%$ of total above-ground biomass. A stepwise regression showed that above-ground biomass was positively correlated with both species richness and dominance in both Field 1 (richness and dominance $P<.002, r^{2}=0.08$ ) and Field 2 (richness and dominance $P<.001, r^{2}=0.37$ ). Duffy [36], in a review of the literature, suggests that the dominant influence of individual species in experimental settings may be an artifact of the simplified environments of the experiments and the single response variables that are usually considered (biomass in our case). Duffy [36] concluded that experiments probably underestimated the importance of diversity and evenness to real-world ecosystem functioning.

Evaluations of results ranging from early experiments [37] to more recent ones involving longer time periods and multiple sites $[2,12]$ have led to at least two types of general conclusions: (1) on average, as species richness declines so does productivity; (2) the magnitude and direction of the change depend on the identity and functional form of the species involved. Specifically, Marquard et al. [38] in an analysis of experimental grasslands in Germany found that above-ground community biomass was positively related to both the number of species functional groups. They concluded that the positive relationship suggests that complementarity is larger between species belonging to different rather than the same functional groups. Results from our study were not able to separate how functional form richness itself may affect plant production, but the stepwise regressions results did produce some useful insights suggesting that the combination of species with different morphological and growth characteristics can significantly influence above-ground biomass and long-term stability.

The hypothesis that stability depends on biological diversity has been intensively debated (e.g., [39-46]). The weight of the empirical data to date provides qualified support for the hypothesis that species richness can increase ecosystem stability, although the underlying mechanisms can differ from theoretical predictions and in many cases still need to be fully resolved [7]. It is, however, important to mention that there are some studies that have shown an inverse relationship between plant diversity and the stability of ecosystem function $[47,48]$. In an extensive analysis of 9 years of data from the USA Cedar Creek LTER site, Tilman [22] found an intriguing dichotomy between population and ecosystem stability: species diversity reduced year-toyear variability in biomass at the plant community level but increased it at the species level. Tilman [22] thus argued that this finding reconciles May's theoretical analysis that diversity should lead to instability at the individual species level, with the diversity-stability hypothesis as it applies to the community level. A recent analysis from the BIODEPTH experiments [3] further supports the stabilizing effect of diversity on the temporal variability of above-ground annual net primary production in grasslands through two mechanisms: population asynchrony and overyielding. Results from our study showed a strong increase in the biomass stability of seeded species with species and functional form richness, with the relationship unaffected by species dominance or fertilization levels. Conversely the stability of nonseeded species declined with seeded species richness, and somewhat counter intuitively was the lowest when nonseeded species were the dominant ones. The last result was a surprise since Polley et al. [49] have shown that in the southern tall grass prairie biomass varied relatively little in restored prairies because they tend to be dominated by one species (Schizachyrium scoparium) whose biomass varied less than the biomass of other dominant and subdominant species. They conclude that, in these grasslands, biomass response to natural variation in precipitation depended as much on characteristics of a dominant grass as on differences in diversity.

An extensive review of published scientific results by Hooper et al. [7] suggests that the invasion of a plant community is strongly influenced by species composition and generally decreases with species and functional form 
richness. Hooper et al. [7] add the caveat that several other factors, such as propagules pressure, disturbance regime, and resource availability, strongly influence invasion success and often override effects of species richness. One of these cases is the results from Foster et al. [47] which found that grassland community susceptibility to invasion was higher in high diversity sites because of extrinsic factors that contribute to spatial variation in diversity (soil disturbances, light availability), not to any direct impact of plant diversity itself. Other studies [50], however, have shown that in drier grasslands (eastern Montana) communities with lower species richness were more heavily invaded (by Centaurea stoebe) than the ones with greater species richness. A further analysis of the invasion problem by Rinella et al. [51] showed that, on a per-gram-of-biomass basis, each resident plant group similarly suppressed the growth of Centaurea stoebe. They concluded that, in order to prevent invasion, maintaining overall productivity is probably more important than maintaining the productivity of particular plant groups or species and that intense disturbances (prolonged drought, overgrazing, etc.) that deplete multiple plant groups may often be a prerequisite for invasion. Results from our study are unambiguous: in both sites invasion of nonseeded species drastically declined with species and functional form richness as well as with the biomass of seeded species.

Dimitrakopoulos et al. [52] showed that fire and species richness had interactive effects on above-ground biomass production, with fire increasing the biomass of species-rich communities. They also showed that species-rich communities are more resistant to fire than species-poor communities. We did not use fire as a treatment, but Field 1 was burned in 2007 as part of the site management. We analyzed the relationship between biomass and species richness for the period before and after burning. Results were mixed. In the high $\mathrm{N}$ treatment, biomass was substantially higher after burning than before burning (446 \pm 82 versus $291 \pm$ $45 \mathrm{~g} \cdot \mathrm{m}^{-2}$ ) even though growing season precipitation was lower (385 versus $458 \mathrm{~mm}$ ). The relationship with species richness, however, went from a positive one before burning $(r=0.51, P<.001)$ to a negative one after burning $(r=-0.6, P<.001)$. Fire, thus, increased biomass but the species-rich sites were less resistant to burning than the species-poor ones. This may have resulted from the fact that the species-poor sites tended to be dominated by Bromus inermis (either through planting or invasion), a species that tends to be resistant to fire. The biomass on the low $\mathrm{N}$ and both $\mathrm{P}$ treatments was unaffected by fire $\left(245 \pm 82 \mathrm{~g} \cdot \mathrm{m}^{-2}\right.$ before versus $249 \pm 82 \mathrm{~g} \cdot \mathrm{m}^{-2}$ after burning). The slope of the regression between biomass and species richness, however, was substantially higher after burning (slope $=58, r=0.81$, $P<.001$ ) than before it (slope $=11, r=0.51, P<.001$ ), suggesting a positive interaction between biomass, fire, and species richness.

In summary,

(i) in both the wetter and drier sites of the northern Great Plain grasslands, the above-ground biomass and the long-term stability of the biomass increased with plant species and functional form richness; (ii) in both sites, during the first 5 years of growth, above-ground biomass was higher and year-to-year variability lower when the species in the mixture had (1) high relative growth rates, root density, root surface area, or N root uptake rates; (2) low rootto-shoot ratio (high biomass allocation to stems and leaves) and $\mathrm{N}$ use efficiency;

(iii) in the wetter site, there was a change after 12 years of growth. $\mathrm{N}$ root uptake rates and root surface area continue to be positively related to biomass, but relative growth rates were not, and $\mathrm{N}$ use efficiency went from a negative ( 6 years after planting) to a positive correlation with biomass production;

(iv) in both sites the invasion of nonseeded species into seeded plots substantially declined with increases in plant species and functional form richness.

\section{Acknowledgments}

The authors are grateful to Ms. Breanna Paradeis Kobiela and Dr. Kris Ringwall for providing invaluable help in the design and implementation of the field experiments. Support for this study was provided by grants from the National Science Foundation (DEB-9627928) and USDA-NRICGP (93-0051, 99-00979, and 2008-00717).

\section{References}

[1] D. Tilman, D. Wedin, and J. Knops, "Productivity and sustainability influenced by biodiversity in grassland ecosystems," Nature, vol. 379, no. 6567, pp. 718-720, 1996.

[2] E. M. Spehn, A. Hector, J. Joshi et al., "Ecosystem effects of biodiversity manipulations in european grasslands," Ecological Monographs, vol. 75, no. 1, pp. 35-63, 2005.

[3] A. Hector, Y. Hautier, P. Saner et al., "General stabilizing effects of plant diversity on grassland productivity through population asynchrony and overyielding," Ecology, vol. 91, no. 8, pp. 2213-2220, 2010.

[4] L. N. Gillman and S. D. Wright, "The influence of productivity on the species richness of plants: a critical assessment," Ecology, vol. 87, no. 5, pp. 1234-1243, 2006.

[5] B. J. Cardinale, J. P. Wright, M. W. Cadotte et al., "Impacts of plant diversity on production increase through time due to complementary resource use: a meta-analysis," Proceedings of the National Academy of Sciences of the United States of America, vol. 104, no. 46, pp. 18123-18128, 2007.

[6] Y. Bai, J. Wu, Q. Pan et al., "Positive linear relationship between productivity and diversity: evidence from the eurasian steppe," Journal of Applied Ecology, vol. 44, no. 5, pp. 1023-1034, 2007.

[7] D. U. Hooper, F. S. Chapin III, J. J. Ewel et al., "Effects of biodiversity on ecosystem functioning: a consensus of current knowledge," Ecological Monographs, vol. 75, no. 1, pp. 3-35, 2005.

[8] C. T. Osborn, F. Lacuna, and M. Linsenbigler, "The conservation reserve program: enrollment statistics for signup periods 1-11 and fiscal years 1990-92," Technicle Report, Resources and Technology Division, Economic Research Service: U.S. Department of Agriculture, Washington, DC, USA, 1992. 
[9] Farms Service Agency, "Conservation reserve program: annual summary and enrollment statistics-FY 2009," 2009, http:// www.fsa.usda.gov/Internet/FSA_File/fyannual2009.pdf.

[10] H. Johnson and M. D. Schwartz, "The conservation reserve program: habitat for grassland birds," Great Plains Research, vol. 3, no. 2, pp. 273-295, 1993.

[11] M. E. Biondini, "Plant diversity, production, stability, and susceptibility to invasion in restored northern tall grass prairies (United States)," Restoration Ecology, vol. 15, no. 1, pp. 77-87, 2007.

[12] D. Tilman, P. B. Reich, J. Knops, D. Wedin, T. Mielke, and C. Lehman, "Diversity and productivity in a long-term grassland experiment," Science, vol. 294, no. 5543, pp. 843-845, 2001.

[13] W. T. Barker and W. C. Whitman, "Vegetation of the northern great plains," Rangelands, vol. 6, pp. 266-272, 1988.

[14] N. Levang-Brilz and M. E. Biondini, "Growth rate, root development and nutrient uptake of 55 plant species from the great plains grasslands, U.S.A," Plant Ecology, vol. 165, no. 1, pp. 117-144, 2002.

[15] M. Biondini, "A three dimensional spatial model for plant competition in an heterogeneous soil environment," Ecological Modelling, vol. 142, no. 3, pp. 189-225, 2001.

[16] H. Johnson and M. E. Biondini, "Root morphological plasticity and nitrogen uptake of 59 plant species from the great plains grasslands, U.S.A," Basic and Applied Ecology, vol. 2, no. 2, pp. 127-143, 2001.

[17] J. D. Bakker, S. D. Wilson, J. M. Christian, X. Li, L. G. Ambrose, and J. Waddington, "Contingency of grassland restoration on year, site, and competition from introduced grasses," Ecological Applications, vol. 13, no. 1, pp. 137-153, 2003.

[18] K. F. Higgins, "Lightning fires in north dakota grasslands and in pine-savanna lands of south dakota and montana," Journal of Range Management, vol. 37, no. 2, pp. 100-103, 1984.

[19] C. D. Bonham, Measurements for Terrestrial Vegetation, John Wiley and Sons, New York, NY, USA, 1989.

[20] S. Naeem, "Disentangling the impacts of diversity on ecosystem function in combinatorial experiments," Ecology, vol. 83, no. 10 , pp. 2925-2935, 2002.

[21] B. McCune and J. B. Grace, Analysis of Ecological Communities, MjM Software Design, Gleneden Beach, Ore, USA, 2002.

[22] D. Tilman, "Biodiversity: population versus ecosystem stability," Ecology, vol. 77, no. 2, pp. 350-363, 1996.

[23] B. J. Winer, Statistical Principles in Experimental Design, McGraw-Hill, New York, NY, USA, 1962.

[24] G. W. Snedecor and W. G. Cochran, Statistical Methods, vol. 9, The Iowa State University Press, Ames, Iowa, USA, 1967.

[25] J. Weisberg, Applied Linear Regression, John Wiley and Sons, New York, NY, USA, 1980.

[26] D. U. Hooper, "The role of complementarity and competition in ecosystem responses to variation in plant diversity," Ecology, vol. 79, no. 2, pp. 704-719, 1998.

[27] H. Bessler, V. M. Temperton, C. Roscher et al., "Aboveground overyielding in grassland mixtures is associated with reduced biomass partitioning to belowground organs," Ecology, vol. 90, no. 6, pp. 1520-1530, 2009.

[28] J. D. Fridley, "The influence of species diversity on ecosystem productivity: how, where, and why?" Oikos, vol. 93, no. 3, pp. 514-526, 2001.

[29] J. He, F. A. Bazzaz, and B. Schmid, "Interactive effects of diversity, nutrients and elevated $\mathrm{CO}_{2}$ on experimental plant communities," Oikos, vol. 97, no. 3, pp. 334-348, 2002.

[30] Q. Guo, T. Shaffer, and T. Buhl, "Community maturity, species saturation and the variant diversity- productivity relationships in grasslands," Ecology Letters, vol. 9, no. 12, pp. 1284-1292, 2006.

[31] J. Hughes and J. Roughgarden, "Species diversity and biomass stability," The American Naturalist, vol. 155, no. 5, pp. 618627,2000

[32] I. Nijs and J. Roy, "How important are species richness, species evenness and inter-specific differences to productivity? A mathematical model," Oikos, vol. 88, no. 1, pp. 57-66, 2000.

[33] M. W. Schwartz, C. A. Brigham, J. D. Hoeksema, K. G. Lyons, M. H. Mills, and P. J. van Mantgem, "Linking biodiversity to ecosystem function: implications for conservation ecology," Oecologia, vol. 122, no. 3, pp. 297-305, 2000.

[34] B. J. Wilsey and C. Potvin, "Biodiversity and ecosystem functioning: importance of species evenness in an old field," Ecology, vol. 81, no. 4, pp. 887-892, 2000.

[35] H. W. Polley, B. J. Wilsey, and J. D. Derner, "Do species evenness and plant density influence the magnitude of selection and complementarity effects in annual plant species mixtures?" Ecology Letters, vol. 6, no. 3, pp. 248-256, 2003.

[36] J. E. Duffy, "Why biodiversity is important to the functioning of real-world ecosystems," Frontiers in Ecology and the Environment, vol. 7, no. 8, pp. 437-444, 2009.

[37] P. M. Vitousek and D. U. Hooper, "Biological diversity and terrestrial ecosystem biogeochemistry," in Biodiversity and Ecosystem Function, E. D. Schulze and H. A. Mooney, Eds., pp. 3-14, Springer, New York, NY, USA, 1993.

[38] E. Marquard, A. Weigelt, V. M. Temperton et al., "Plant species richness and functional composition drive overyielding in a six-year grassland experiment," Ecology, vol. 90, no. 12, pp. 3290-3302, 2009.

[39] R. M. May, Stability and Complexity in Model Ecosystems, Princeton University Press, Princeton, NJ, USA, 1973.

[40] S. J. McNaughton, "Diversity and stability of ecological communities: a comment on the role of empiricism in ecology," The American Naturalist, vol. 111, no. 979, pp. 515-525, 1977.

[41] D. A. Frank and S. J. McNaughton, "Stability increases with diversity in plant communities: empirical evidence from the 1988 Yellowstone drought," Oikos, vol. 62, no. 3, pp. 360-362, 1991.

[42] D. Tilman and J. A. Downing, "Biodiversity and stability in grasslands," Nature, vol. 367, no. 6461, pp. 363-365, 1994.

[43] D. F. Doak, D. Bigger, E. K. Harding, M. A. Marvier, R. E. O'Malley, and D. Thomson, "The statistical inevitability of stability-diversity relationships in community ecology," The American Naturalist, vol. 151, no. 3, pp. 264-276, 1998.

[44] D. Tilman, C. L. Lehman, and C. E. Bristow, "Diversitystability relationships: statistical inevitability or ecological consequence," The American Naturalist, vol. 151, no. 3, pp. 277-282, 1998.

[45] D. Tilman, "The ecological consequences of changes in biodiversity: a search for general principles," Ecology, vol. 80, no. 5, pp. 1455-1474, 1999.

[46] K. S. McCann, “The diversity—stability debate," Nature, vol. 405, pp. 225-228, 2000.

[47] B. L. Foster, V. H. Smith, T. L. Dickson, and T. Hildebrand, "Invasibility and compositional stability in a grassland community: relationships to diversity and extrinsic factors," Oikos, vol. 99, no. 2, pp. 300-307, 2002.

[48] A. B. Pfisterer and B. Schmid, "Diversity-dependent production can decrease the stability of ecosystem functioning," Nature, vol. 416, no. 6876, pp. 84-86, 2002.

[49] H. W. Polley, B. J. Wilsey, and J. D. Derner, "Dominant species constrain effects of species diversity on temporal variability in 
biomass production of tallgrass prairie," Oikos, vol. 116, no. 12, pp. 2044-2052, 2007.

[50] J. Maron and M. Marler, "Native plant diversity resists invasion at both low and high resource levels," Ecology, vol. 88, no. 10, pp. 2651-2661, 2007.

[51] M. J. Rinella, M. L. Pokorny, and R. Rekaya, "Grassland invader responses to realistic changes in native species richness," Ecological Applications, vol. 17, no. 6, pp. 1824-1831, 2007.

[52] P. G. Dimitrakopoulos, A. S. D. Siamantziouras, I. Mprezetou, and A. Y. Troumbis, "The interactive effects of fire and diversity on short-term responses of ecosystem processes in experimental Mediterranean grasslands," Environmental Management, vol. 37, no. 6, pp. 826-839, 2006. 

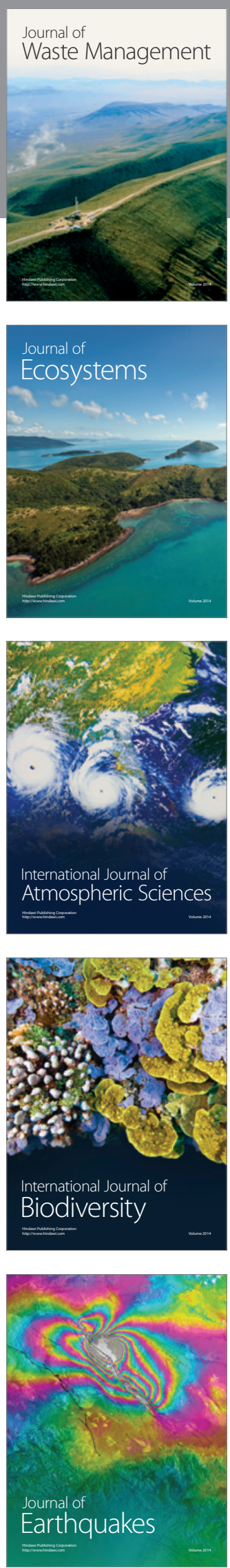
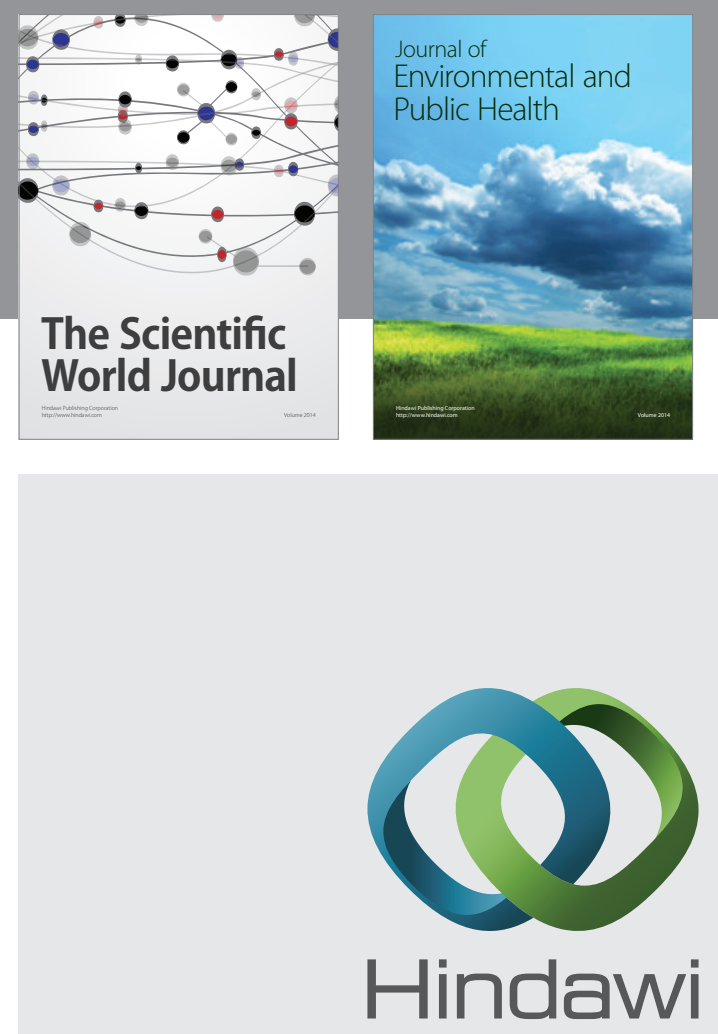

Submit your manuscripts at

http://www.hindawi.com
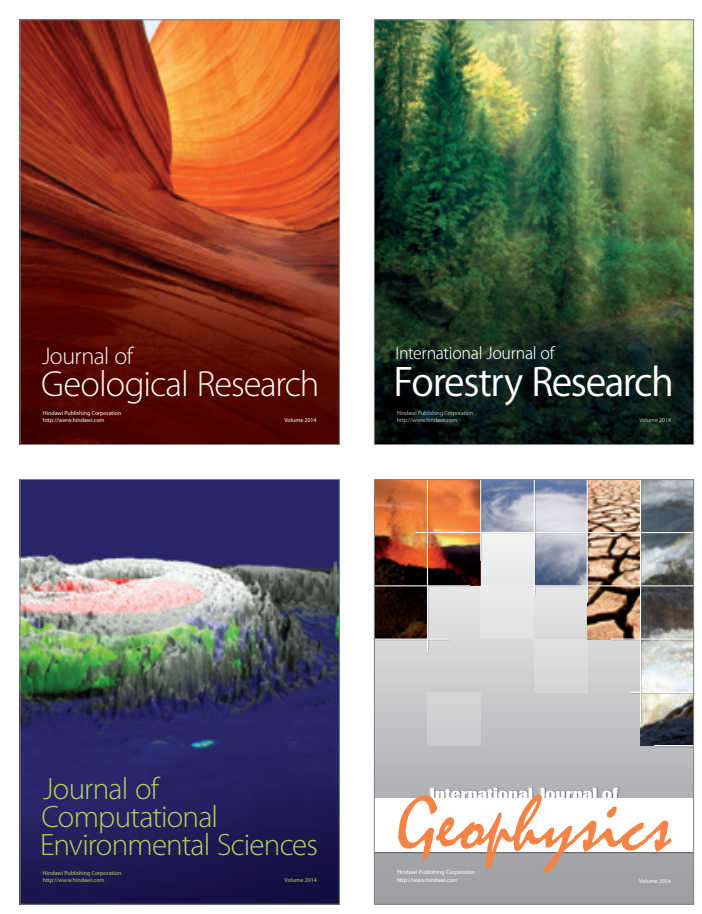
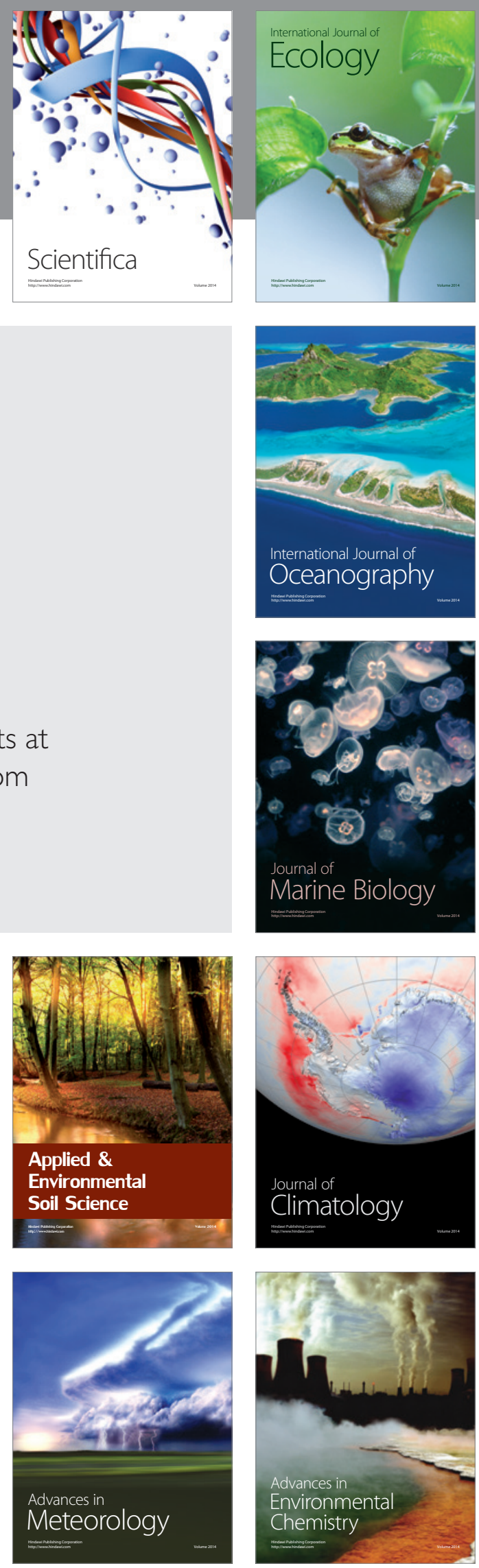